\title{
アルファ粒子のリップル損失に関連する研究の現状
}

\author{
谷 啓二, 滝堟知典, 安積正史
}

（日本原子力研究所）

(1991年 5 月13日受理)

\section{Recent Studies of Ripple Losses of Alpha Particles}

\author{
Keiji Tani, Tomonori Takizuka and Masafumi Azumi
}

(Received May 13, 1991)

\begin{abstract}
Studies of ripple losses of alpha particles in tokamak reactors have been reviewed with particular reference to the results from recent benchmark test for ITER. Recent studies of losses of alpha particles incidental to applied techniques making use of field ripple such as burn control and refueling have also been described.
\end{abstract}

Keywords:

alpha particle, ripple loss, ITER, burn control, refueling,

\section{1.はじめに}

トカマクプラズマ中には熱化イオンに加え, 中性粒子入物や波動加熱, 核反応等により高エネルギー粒子 か生成される。これらの高エネルギー粒子の良好な閉じ込めは，プラズマ加熱の効率を上げるうえで重要な 課題である，特に核反応生成アルファ粒子の閉じ込めは，核燃焼トカマクを考えるうえで必須の条件であ る. 本解説では, トカマクにおけるアルファ粒子の古典的閉じ込めと関連する問題の研究の現状について報 告する.

トカマクにおいては, アルファ粒子のバナナ巾のプラズマ小半径に対する割合は10２0\%に達する場合も あり，速度空間上に非常に大きなロスコーンを形成する。しかしながら，アルファ粒子の発生は，その強い 温度依存性から，プラズマ中心付近に集中するため軸対称磁場中では $Z_{\mathrm{eff}}$ が小さければ，その減速過程で 失われるパワーの割合は全体の 2 〜 \% 程度であることが軌道追跡モンテカルロ (orbit-following MonteCarlo : OFMC) コードにより数值的に解析されている1）。従って軸対称磁場中でのアルファの閉じ込めは極

Naka Fusion Research Establishmant, Japan Energy Research Institute, Ibaraki 311-01. 
めて良好であり, 核融合炉設計上問題はほとんどないと考えてよい。これに対し, 中性粒子入射加熱で生成 される高速イオンの非軸対称磁場中での挙動に関して幾つかの研究がなされてきた ${ }^{2,3,4)}$ ，それ等の結果は いずれも, 非軸対称磁場の代表であるトロイダル磁場リップル（トロイダル磁場コイルが有限の個数に分割 されているために、コイルとコイルの間で生じるわずかな磁場の強弱, 以後, 単にリップルと称する) によ り, 高エネルギー粒子の輸送が軸対称磁場中のそれに比べて非常に大きくなることを示している。このこと から，高エネルギーアルファ粒子の古典的輸送も，リップルによりほぼ決定されるものと考えられている． このアルファ粒子のリップル損失は，アルファ粒子加熱効率及び損失粒子による熱負荷の問題から，トロイ ダル磁場コイル及び真空容器第 1 壁の設計に重大な影響を及ぼし，核融合炉設計上最重要課題の 1 つとなっ ている。このようなリップルの否定的な側面とは対照的に，最近の研究では，リップル効果を制御手段に応 用しうることが明らかになってきている。

本解説においては，第 2 章でアルファ粒子の減速過程で発生するリップル損失に関連して，最近行われた ITER ベンチマークテスト 結果 ${ }^{5)}$ を心に，各国の解析手法，損失粒子による真空容器第 1 壁上の熱負荷 を，第 3 章では，核融合炉における核燃焼制御，燃料補給などのリップル応用に関連するアルファ粒子損失 を各々まとめる。

\section{2. $\alpha$ 粒子の減速過程におけるリップル損失}

$\alpha$ 粒子の減速過程で発生する総損失量の評価には,

(1) $\alpha$ 粒子ソース分布

(2) リップル分布

(3) 損失過程

の全てを同時に考慮する必要がある。このため，解析的手法を用いて定量的に評価することは非常に困難で あり，主として 3 次元軌道追跡モンテカルロ（OFMC）コードを用いた数值解析が行われてきたＯFMCコー ドによる検討は，もう既に 10 年近くの歴史をもつが，問題の複雑さと膨大な数値計算に対する不信感から， 依然ベンチマークテストの必要性が論じられている，従って，これまで $\alpha$ 粒子の総損失量は系統的に評価さ れたことはなく，個々の装置毎に $\alpha$ 粒子閉じ込めの予測，損失粒子による真空容器第 1 壁上の局所熱負荷が 検討されて来たに過ぎない.

その中で, INTOR, ITER の国際共同設計作業の持つ意味は極めて大きい. 例えば，1984年 INTOR のベン チマークテストにおいて発生した谷-Hively 論争 ${ }^{6,7)}$ では, Hively コードにおける数值解法のわずかな誤 りがアルファ粒子損失量の評価に大きな影響を与えることが明らかになり, 厳密な数值解法と実形状配位で の解析がアルファ粒子損失量の定量的評価に不可欠であることが認識された。この成果をうけて, ITERに おいては, かなり慎重に, また, 各国の計算機事情の差もあり, 表 1 に示すように異なった解析手法でベン チマークテストが行われた，以下，その内容とこれまで報告されている関速する解析結果をまとめる. 
表 1 各国におけるITER ベンチマークテスト解析手法

\begin{tabular}{|c|c|c|c|c|}
\hline $\begin{array}{l}\text { Group } \\
\text { References }\end{array}$ & $\begin{array}{l}\text { EC } \\
\text { (Bittoni) }\end{array}$ & $\begin{array}{l}\text { JAPAN } \\
\text { (Tani) }\end{array}$ & $\begin{array}{l}\text { USA } \\
\text { (White) }\end{array}$ & $\begin{array}{l}\text { USSR } \\
\text { (Smirnov) }\end{array}$ \\
\hline MHD Equilibrium & $\begin{array}{l}\text { finite- } \beta, \text { noncircular } \\
2 \mathrm{D}(R, Z) \\
\text { given } \mathrm{J}(\Psi) \text { profile }\end{array}$ & $\leftarrow$ & $\begin{array}{l}\leftarrow \\
\leftarrow \\
\text { given } p(\Psi), q(\Psi) \\
(\text { PEST) }\end{array}$ & $\begin{array}{l}\leftarrow \\
2 \mathrm{D}(R, Z) \text { and } \\
2 \mathrm{D} \text { inverse } \\
\text { given } J(\Psi)\end{array}$ \\
\hline Field model & $2 \mathrm{D}+$ ripple & $\leftarrow$ & $\leftarrow$ & $\leftarrow$ \\
\hline TF ripple field & $\begin{array}{l}\text { filament current } \\
\text { for TF coils }\end{array}$ & $\begin{array}{l}\text { sheet current } \\
\text { for TF coils }\end{array}$ & $\begin{array}{l}\text { numerical grid } \\
\text { of ripple values }\end{array}$ & $\begin{array}{l}\text { multi-filament } \\
\text { for TF coils }\end{array}$ \\
\hline Model of alpha-losses & $\begin{array}{l}\text { Orbit following } \\
\text { Monte-Carlo (OFMC) }\end{array}$ & OFMC & $\begin{array}{l}\text { stochastic loss model } \\
\left(\text { for } \delta>\delta_{\min }\right)^{a}\end{array}$ & OFMC+mapping \\
\hline Orbit integration & $\begin{array}{l}\text { 5th order Runge-Kunge-Kutta } \\
\text { full guiding center }\end{array}$ & $\begin{array}{l}\text { 2nd order } \mathrm{R}-\mathrm{K} \\
\text { guiding center } \mathrm{O}(4)\end{array}$ & $\begin{array}{l}\text { 5nd order R-K } \\
\text { vectorized }\end{array}$ & $\begin{array}{l}\text { 4th order } \mathrm{R}-\mathrm{K} \\
\text { guiding center } \mathrm{O}(4)\end{array}$ \\
\hline Time scale enhancement & $\begin{array}{l}\text { banana:none } \\
\text { transit:200 }\end{array}$ & $\begin{array}{l}\text { banana: none } \\
\text { transit:200 }\end{array}$ & none & none \\
\hline Particle loss & $\begin{array}{l}\text { counted at } 1 \text { st wall } \\
\text { within one gyroradius }\end{array}$ & $\leftarrow$ & lost if stochastic ${ }^{b}$ & $\begin{array}{l}\text { counted at } 1 \text { st wall } \\
\text { (flux surface) }\end{array}$ \\
\hline Collisions & $\begin{array}{l}\text { slowing down } \\
\text { pitch angle scattering } \\
\text { velocity diffusion }\end{array}$ & $\begin{array}{l}\leftarrow \\
\leftarrow \\
\leftarrow\end{array}$ & $\leftarrow$ & $\begin{array}{l}\leftarrow \\
\leftarrow \\
\text { velocity diffusion }\end{array}$ \\
\hline
\end{tabular}

${ }^{a}$ OFMC is also available. ${ }^{b}$ In the case of OFMC (code ORBIT), paricle loss counted at last flux surface.

\section{2-1） $\alpha$ 粒子損失量評価}

$\alpha$ 粒子が発生してから熱化されるまでにプラズマから失われる過程には,

1 ) 即時損失 (Prompt loss)

2) 非即時損失 (nou-prompt loss)

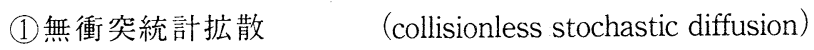

(2)無衝突リップル捕捉 (collisionless ripple-trapping)

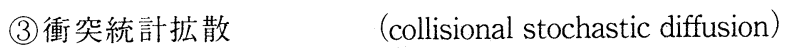

が存在する。上記 1 ) は, 第 1 軌道損失（first-orbit loss）と呼ばれるもので， 1 周期運動以内の粒子損 失を意味する，2）－(1)の概要は，以下の通りである。

リップル磁場中においては, 磁力線に沿った磁場の非軸対称成分の変化率に対する軸対称成分の変化率で 定義されるパラメー夕 


$$
\begin{aligned}
\alpha^{*}= & |\overline{\partial B} / \partial l| /|\tilde{\partial B} / \partial l| \\
= & \operatorname{rin} \theta /(N R q \delta) \cdots \cdots \cdots \text { 円形プラズマ } \\
& R: \text { 主半径 } \\
& r: \text { 小半径 } \\
& \theta: \text { ポロイダル角 } \\
& q: \text { 安全係数 } \\
& \delta: \text { 局所リップル } \\
& l: \text { 磁力線に沿った長さ }
\end{aligned}
$$

が1より小さい場合, 局所的に磁場の最小值（ウェル）が存在するが, 1 より大きい場合は存在しない。一 般に, 荷電粒子は軌道上での存在時間が長くなる, すなわち, 磁力線に沿った速度, U॥が小さくなる所で 磁気面からの $\nabla B$ ドリフト量が大きくなる。軸対称磁場中では, このドリフト量は水平面に対して上下の軌 道上で完全にキャンセルされ，ポロイダル断面へ投影された軌道は 1 周期の運動後に完全に閉じる。しか し，リップル磁場中においては，このドリフト量は必ずしも 1 周期の運動間ではキャンセルされず軌道は閉 じない.この軌道の磁気面からのドリフトは| v ||が0となる点を持つバナナ粒子において特に顕著にな る. 円形断面プラズマ中でのバナナ粒子の場合, 半周期間の $\nabla B$ ドリフトのリップル磁場による寄与は $\alpha^{*}$ が1より十分大きい領域では近似的に

$$
\begin{aligned}
& \Delta r \sim \Delta r^{*} \sin \left(\mathrm{N} \phi_{\mathrm{b}}-\frac{\pi}{4}\right) \\
& \Delta r^{*}=\left(\mathrm{N} \pi / \sin \theta_{\mathrm{b}}\right)^{1 / 2}(q / \varepsilon)^{3 / 2} \rho_{\mathrm{L}} \delta \\
& \rho_{\mathrm{L}}: \text { ラーマ半径 } \\
& \theta_{\mathrm{b}} \cdot \phi_{\mathrm{b}}: \text { バナナチップ点のポロイダル, トロイダル角 } \\
& \varepsilon \quad: \text { バナナチップ点の逆アスペクト比 } \\
& N \quad: \text { トロイダルコイル数 } \\
& \delta \quad: \text { バナナチップ点でのリップル率 }
\end{aligned}
$$

で表わされる4).（2）式に示されるように, 径方向ドリフト量は ダル角 $\phi_{b}$ に依存する，バナナチップ間のトロイダル角差 $\Delta \phi_{\mathrm{b}} \sim 2 \theta_{\mathrm{b}} q$ は径方向位置に依存する。従っ て, バナナチップ点での径方向ドリフトにより，バナナチップのトロイダル角位相が変位を受けるが，その 変化が一定のレベル以上になると軌道がエルゴディックになる。このリップル磁場中でのエルゴディック． 


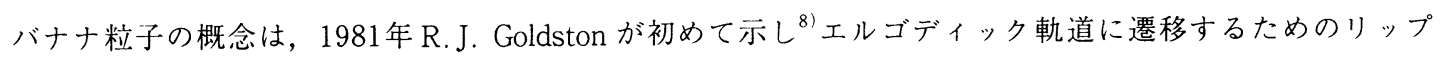
ルによる上下のバナナチップ点間のトロイダル角位相差の変化率として 1 ／ $\mathrm{N}$ を経験的に見出した。すなわち，

$$
\frac{\mathrm{d} \Delta \phi_{\mathrm{b}}}{\mathrm{d} r} \Delta r^{*}=\left(2 \theta_{\mathrm{b}} \frac{\mathrm{d} q}{\mathrm{~d} r}+\frac{2 q}{r} \frac{\cos \theta_{\mathrm{b}}}{\sin \theta_{\mathrm{b}}}\right) \Delta r^{*} \geq \frac{1}{N}
$$

バナナ粒子の代表として $\theta_{\mathrm{b}} \sim \pi / 2$ を選ぶことによりエルゴディック軌道になる臨界リップル率として

$$
\delta_{\mathrm{e}} \sim \frac{1}{(N \pi q / \varepsilon)^{3 / 2} \rho_{\mathrm{L}} \mathrm{d} q / \mathrm{d} r}
$$

が導出ざれた。これは,著者名をとって GWB 臨界リップルと㭔ばれている，2）-(2)は，（1）式の $\alpha^{*}<$

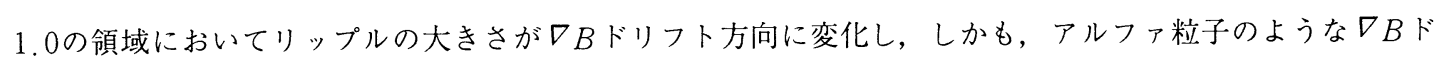
リフトの大きい粒子がバナナチップ点で反射される場合，衝突を介さないでリップルに捕捉される過程であ る2). 2) - (3)は, バナナチップ点の局所リップルが

$$
\delta<\delta_{\mathrm{c}}
$$

であり衝突がなければ非エルゴディック軌道を描く粒子も，プラズマとのクーロン衝突を介してエルゴディ ックになり，輸送を引越す結果発生する損失である ${ }^{6.9)}$.

米国の R.B. White 等は， $\alpha$ 粒子は非常に高エネルギーなので, クーロン衝突の効果は小さくその総損失 量の大部分は 1) と 2) - (1)で決定されると考え， $\delta>\delta_{c}$ となるエルゴディック領域に発生する $\alpha$ 粒子を 数值的に評価（一般にトカマクにおいては 1) の大部分は2）-(1)に含まれる）するコード“RIPLOS”を開 発し ${ }^{(0)}$ ，これを用いた解析を行った。これに対し谷, Goloborod'ko, Kolesnichenko 等の日本, ソ連グル ープは $\alpha$ 粒子といえどもその損失過程にはクーロン衝突効果が重要であるとしている ${ }^{6,11,12)}$.ソ連グルー プは，計算機資源の事情から長時間 CPUの計算は行えないため，粒子軌道積分をマッピング法に置換し， クーロン衝突をモンテカルロ法でさらに， $\alpha^{*}<1.0$ の領域に入った粒子は OFMC で解く, mapping + OFMC の手法を用いている ${ }^{13)}$. 日本と EC は 3 次元 OFMC コードで（ただし，ECは $\alpha$ 粒子におけるクーロン衝突 効果についてはまだ何も表明してはいない。また，OFMCの結果も粒子拡散係数導出に利用し，その拡散係 数から総損失量を後に評価した ${ }^{14)}$ 程度であり，まだOFMCによる総損失量評価は行われていない）総損失 量の評洒を行っている。ベンチマークテストは表 2 に示すパラメータ, 図 1 に示す MHD平衡, リップル分 布，真空容器第 1 壁形状で行われた。結果は表 3 にまとめられている。この時点でまだ結果が得られていな 
表 2 ITER ベンチマークテスト計算パラメータ

\begin{tabular}{|c|c|c|}
\hline major radius & $R_{t}$ & $=5.8 \mathrm{~m}$ \\
\hline minor radius & $a$ & $=2.2 \mathrm{~m}$ \\
\hline toroidal field & $B_{t}$ & $=4.4 \mathrm{~T}$ \\
\hline \multirow[t]{4}{*}{ plasma temperature } & $T_{\mathrm{e}}(\Psi)$ & $=T_{\mathrm{e} 0}(1-\Psi)$ \\
\hline & $T_{i}(\Psi)$ & $=T_{\mathrm{i} 0}(1-\Psi)$ \\
\hline & $T_{\mathrm{D}}(\Psi)$ & $=T_{\mathrm{T}}(\Psi)=\pi_{i}(\Psi)$ \\
\hline & $T_{\mathrm{e} 0}$ & $=T_{\mathrm{i} 0}=20 \mathrm{keV}$ \\
\hline \multirow[t]{3}{*}{ plasma density } & $n_{\mathrm{e}}(\Psi)$ & $=n_{\mathrm{e} 0}(1-\Psi)^{0.5}$ \\
\hline & $n_{D}(\Psi)$ & $=n_{T}(\Psi)=n_{\mathrm{i}}(\Psi)$ \\
\hline & $n_{\mathrm{e} 0}$ & $=2.0 \times 10^{20} \mathrm{~m}^{-3}$ \\
\hline \multirow[t]{2}{*}{ plasma current } & $j(\Psi)$ & $=j_{0}(1-\Psi)^{0.5}$ \\
\hline & $I_{\mathrm{p}}$ & $=22 \mathrm{MA}$ \\
\hline ellipticity & $k$ & $=1.96$ \\
\hline triangularity & $\Delta$ & $=0.55$ \\
\hline effective $Z$ & $z_{\text {eff }}$ & $=1.5$ (uniform) \\
\hline $\begin{array}{l}\text { charge number } \\
\text { of impurity ion }\end{array}$ & $z_{i m p}$ & $=0.8$ (oxygen) \\
\hline $\begin{array}{l}\text { number of toroidal } \\
\text { field coils }\end{array}$ & $N_{\mathrm{t}}$ & $=16$ \\
\hline
\end{tabular}

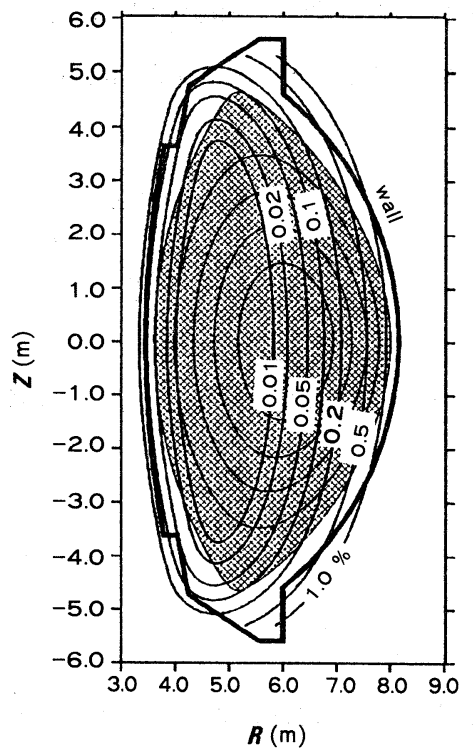

図 1.ITER 物理フェーズにお けるリップル分布, MHD 平衡, 真空容器第 1 壁形 状.

表 3 ベンチマークテスト結果

\begin{tabular}{llll}
\hline $\begin{array}{l}\text { Calculation method/model } \\
\text { (see Table 1) }\end{array}$ & $\begin{array}{l}\text { JAPAN } \\
\text { OFMC }\end{array}$ & $\begin{array}{l}\text { USA } \\
\text { Stochastic } \\
\text { losses only }\end{array}$ & $\begin{array}{l}\text { USSR } \\
\text { OFMC } \\
\text { +mapping }\end{array}$ \\
\hline Power loss fraction (\%) & 0.65 & $0.03-0.9$ & $<1$ \\
& & $0.03-0.9$ & $1<\mathrm{E}<3.5 \mathrm{MeV}$ \\
$\begin{array}{l}\text { Particle loss fraction (\%) } \\
\text { Ripple banana diffusion: }\end{array}$ & 0.9 & & \\
$\begin{array}{l}\text { Toroidal peaking factor } \\
\text { Poloidal peaking factor }\end{array}$ & 1 & $\leq 2$ \\
$\begin{array}{l}\text { Peak load at 1000MW }\left(\mathrm{MW} / \mathrm{m}^{2}\right) \\
\text { Divertor load }\end{array}$ & 0.07 & $\sim 10$ \\
Ripple trapped losses: & yes, but small & $<0.05$ \\
Peak load at $1000 \mathrm{MW}\left(\mathrm{MW} / \mathrm{m}^{2}\right)$ & 0.1 & no \\
\hline
\end{tabular}

いEC を除き， 3 者とも総パワー損失として $1 \%$ 以下で良い一致を示している.

\section{2-2）損失粒子による真空容器第 1 壁上熱負荷}

表 3 の後半には，損失粒子による真空容器第 1 壁上の熱負荷に関する結果がまとめられている，米国 “RIPLOS” コードは計算に必要な CPU は極めて短い特徴をもつ反面，損失粒子による真空容器上の熱負荷 


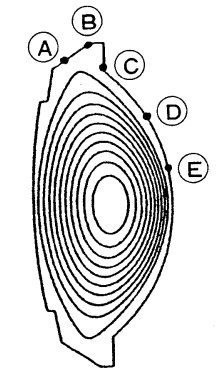

Heat load averaged over toroidal angle

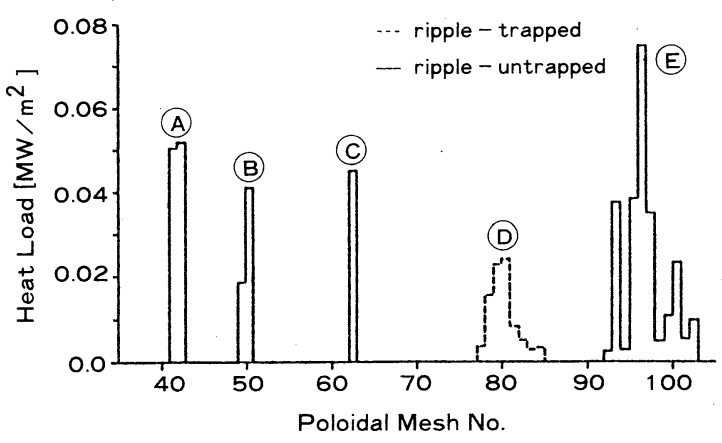

図 2.ITER 物理フェーズにおける $\alpha$ 粒子リップル損 失による真空容器第 1 壁上の熱負荷分布. 実線 及び点線は, リップル非捕捉(バナナドリフト) 粒子及びリップル捕捉損失粒子による熱負荷の トロイダル角平均値.
の評価ができない問題を含んでいる。そこ で, ITER ベンチマークでは, 日ソ両グルー プの結果が報告されるに留まった。以下，日 本グループの結果を例としてまとめる.

第 1 壁上の熱負荷分布はバナナドリフト損 失粒子とリップル捕捉損失粒子で大きく異な る ${ }^{15)}$. 前者は, ポロイダル方向, トロイダ ル方向いずれもそのピーキングはあまり強く ないのに対し，後者は両方向に非常に強いピ 一キングを示す。従って；第 1 壁上の局所熱 負荷としては，特に後者に注意を要する． ITER は，アスペクト比がA〜2.8と非常に低 く, しかもトロイダルコイル数が $\mathrm{N}=16$ と大 きいため, プラズマ中でリップルは非常に強 く減衰する。このため, リップルによる $\alpha$ 粒 子パワー損失もバナナドリフト損失, リップ ル捕促損失は各々 $0.5,0.1 \%$ と非常に低いの が特色である：図 2 に OFMCコードで計算さ

れた，真空容器熱負荷のトロイダル角平均值を示す。実線はバナナドリフト損失粒子による熱負荷，点線は リップル捕促損失粒子によるものである。ポロイダル角上で $\mathrm{A}$ E ま での真空容器断面図上に示す位置に熱 負荷が観測される. ITERの設計においては，ダイバータ部などの強制冷却機能のある部分とそうでない部 分の許容熱負荷は各々 $10 \mathrm{MW} / \mathrm{m}^{2}$ 及び0.2 0.3MW $/ \mathrm{m}^{2}$ である ${ }^{16)}$. 図 2 の(A), B)は熱容量の大きいダイバータ 部への熱入力であり特に問題とはならない。点は真空容器上のエッジを丸くすれば問題とはならなくなる であろう，従って，熱負荷上問題となるのは，強制冷却機能のない部分でのピーク (D) と可であ。図 3 に リップル捕捉損失粒子による 2 次元熱負荷分布を示す。前述のようにリップル捕捉損失粒子はトロイダ ル，ボロイダルいずれの方向にも極めて限定された領域に流入する。このため，たとえ損失そのものが小さ くても，局所熱負荷として問題となりうる。このことから，リップル捕捉損失に関しては，図 2 に示すよう なトロイダル角平均值は意味を持たない. ITERの場合, このリップル捕捉損失粒子による熱負荷のピーク值 は $0.1 \mathrm{MW} / \mathrm{m}^{2}$ であり，許容值の範囲内であることが判った。一方，図 4 にバナナドリフト損失粒子による 2 次元熱負荷分布を示す。問題のE点における熱負荷は, トロイダル角方向にはピーク点を持たないように 見える.INTORにおける同様の結果では，トロイダル角方向にも多少のピークが観測されている6）これら の計算上の相異点は, INTORの結果は, プラズマ表面と真空容器を一致させ， $\alpha$ 粒子のラーマ半径を 


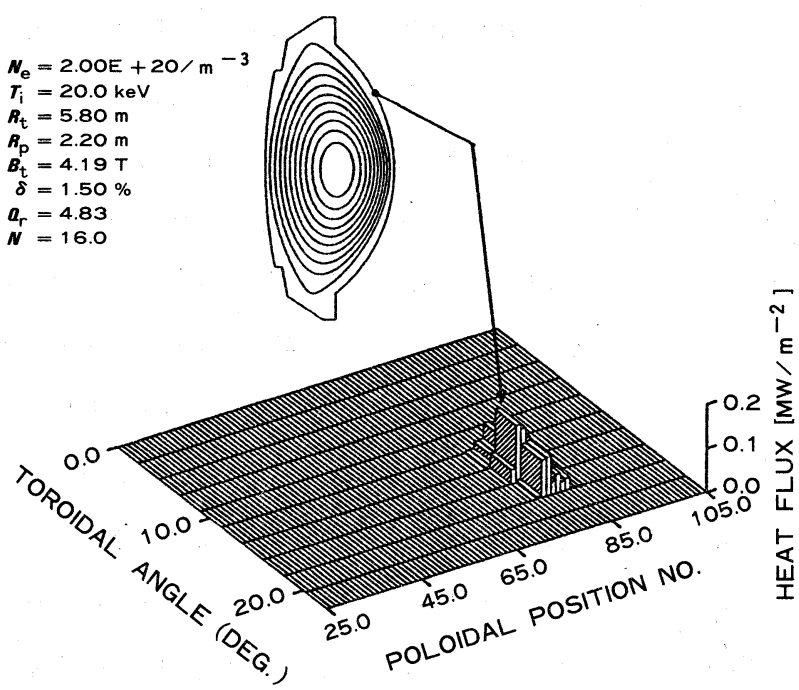

図 3.ITER 物理フェーズにおける，リップル捕捉損失 $\alpha$ 粒子による真空容器第 1 壁上の 2 次元熱負荷分布。

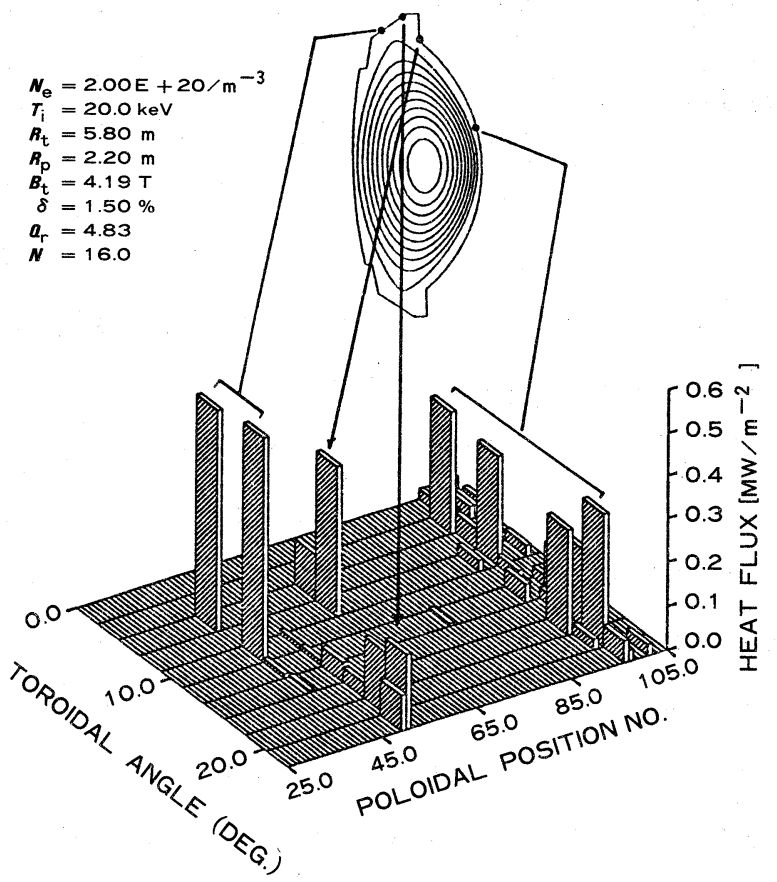

図 4.ITER 物理フェーズにおける，バナナドリフト 損失粒子による真空容器第 1 壁上の 2 次元熱負 荷分布.
0 とした結果であるのに対し, ITER で は，プラズマと真空容器時間にギャップ を設け，有限なラーマ半径を考慮して真 空容器への粒子の流入点を計算したもの である。これ等の相違点のいずれか，あ るいは,リップルの大きさなど他のパラ メータの違いにより熱負荷のトロイダル 角依存性が異なってくるのか，あるいは 単なるモンテカルロ計算精度の問題であ るのかは現時点では不明であり，将来の 研究課題として残されている．現時点の OFMC の計算結果を信用すれば，ITER ではトロイダル角方向のピーキングファ

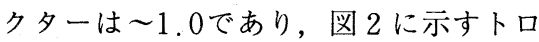
イダル角平均の熱負荷が意味を持ち，そ の最大熱負荷は0.07〜0.08MW $/ \mathrm{m}^{2}$ であ る。この值は,リップル捕捉損失による ピーク熱負荷よりも多少小さく，また， 両者の重なりもないことから, 許容熱負 荷の範囲内である。

以上のように，ITER はかなり極端な 例ではあるが，一般に将来の核融合炬で は,リップル損失量そのものはプラズマ のエネルギーバランス上問題とはならな い.むしろ損失粒子による真空容器上の 局所熱負荷でリップルの許容值が決ま る。この場合，熱負荷の 2 次元分布まで 求める必要があり, 計算上大きな問題と なる，例えば，前述のITER の計算では OFMC コードでリップル損失を求める場 合1000個のテスト粒子の減速過程を追跡 するのに世界最高速クラスのベクトル計 
算機を用いても10数時間かかる．熱負荷の 2 次元分布を導出するには少なくとも20000〜30000個のテスト粒 子が必要であり CPU として数100時間が必要となる。今後, 並列計算技術を導入した高速化あるいは, ソ連 グループのような新しい計算手法の開発が待たれる.

\section{3. 核融合炉へのリップル応用に関連する $\alpha$ 粒子損失}

リップルの核融合炉への応用としては,

(1)核燃焼制御

(2)燃料補給

の 2 つがこれまで考えられてきた.リップルは $\alpha$ 粒子にとっては必ず損失を増やす方向に作用する．上記の 応用のうち，(1)はリップルによる $\alpha$ 粒子閉じ込めの劣化そのものを利用するものであり，(2)は $\alpha$ 粒子のリッ プル損失によりその有効性が制限を受けるものである.

\section{3ー1）リップルを利用した核燃焼制御}

核然焼プラズマの温度制御へのリップルの応用は，古くからいくつかの提案がなされている．まず，バル クイオンの collisional ripple-trapping, detrappingによるイオン熱伝導係数が

$$
\chi_{\mathrm{i}}^{\mathrm{RT}} \propto \mathrm{T}_{\mathrm{i}}^{7 / 2}
$$

であることが理論的に予測されていたが17)，その強いイオン温度依存性に着目し，トロイダル磁場コイル で自然に発生するリップルを用いた受動制御 ${ }^{18)}$ あいは，外部リップルコイルによる能動制御 19,20$)$ など が考えられた。しかし，その後, OFMCコードによる $\chi_{\mathrm{i}}^{\mathrm{RT}}$ の数值解で, 衝突周波数の低くなる高温領域で 理論值よりも 1 桁以上低く, また, 温度依存性も（6）式ほど強いものではなく, 高々 $T_{\mathrm{i}}^{2}$ 程度となるこ とが示された ${ }^{21,22)}$. このことから，従来の $\chi_{\mathrm{i}}^{\mathrm{RT}}$ を利用する方法は疑問視され，しばらくの間リップルの 核然焼制御への応用は考えられていなかった。しかし，最近，前章で述べた $\alpha$ 粒子のリップルによる閉じ込 め劣化を利用する新しい核燃焼制御方法が提案された ${ }^{12,23)}$.その制御方法として,

(1)外部リップルによるフィードバック制御,

(2)一定の垂直磁物中で $\beta$ 值増大に伴うプラズマの主半径方向の自由膨脹でよりリップルの大きい領 域へプラズマが移動し， $\alpha$ 粒子のリップル損失の増加で自動的に実現される受動核燃焼制御,

(3)上に(1)と(2)の組み合せ,

が考えられた。その詳細な内容については, 文献 $[12,23]$ に任せることにしここでは，その結果の紹介 にとどめる. 計算は, 主半径〜 $7.5 \mathrm{~m}$, 小半径 $1.8 \mathrm{~m}$, 核融合出力〜 $3 \mathrm{GW}$ クラスの核融合炉を想定して行われ た。 
まず,フィードバック制御を“Switchedoff” した受動制御に拝けるプラズマ中心のイ オン温度 $\mathrm{T}_{\mathrm{i} 0}$, 核融合出力 $\mathrm{Q}_{\mathrm{F}}$, 主半径 $\mathrm{R}$, プ ラズマのトーラス外側端でのリップル $\delta_{0}, \alpha$ 粒子パワー損失比 $G_{\mathrm{t}}$ の時間变化を図 5 に示 す。（a）は主半径を固定し，何ら制御しな かった場合の結果であり，熱平衡に達してから ほんの $2 \sim 3$ 秒で急激に温度が上昇する熱的不 安定性が示されている。（b）は $\alpha$ 粒子のリッ プル損失を考慮せずプラズマの自由膨脹（ $(\mathrm{d} R /$ $\mathrm{d} \beta_{\mathrm{p}}=3.6 \mathrm{~m} ）$ のみを考えた場合の結果である が， $R$ を $8.2 \mathrm{~m}$ で制限したため，これに到達し た後（a）と同様に熱的不安定性が起こること が示されている。（c）は，自由膨脹に加え， $\alpha$ 粒子のリップル損失を考慮した場合の結果で ある。主半径は $7.3 \mathrm{~m}$ から $8.0 \mathrm{~m}$ まで脵脹し，約 $20 \% の \alpha$ 粒子パワー損失が発生して熱的な平衡 に到達している様子が示されている。ささらに，

リップルのフィードバック制御を考慮した場合 の結果が図 6 である。外部リップルコイルによ るリップルのフィードバック制御の時間遅れと しては $\tau_{\mathrm{d}} \sim 1.0$ 秒を仮定した。（a）は， $\mathrm{d} R /$ $\mathrm{d} \beta_{\mathrm{p}}=0.0$ とし, フィードバック制御のみを考 えた場合のものである。点線はトーラス外側端 でのリップルのうち，外部リップルによる制御 リップルを示す，核燃焼温度の制御は実現され ているものの， $\tau_{\mathrm{d}}=1.0$ 秒と長く設定している ため， $Q_{\mathrm{F}}, G_{\mathrm{t}}$ 等にオーバシュートが観測され る。これに対し，（b）に示すように $\mathrm{d} R /$ $\mathrm{d} \beta_{\mathrm{p}}=3.6$ とし主半径の自由膨脹を許した場 合， $\mathrm{R}=7.3 \mathrm{~m}$ から $7.6 \mathrm{~m}$ とほんの僅かな膨脹 でリップル損失も15\%と図 5 の結果より低い
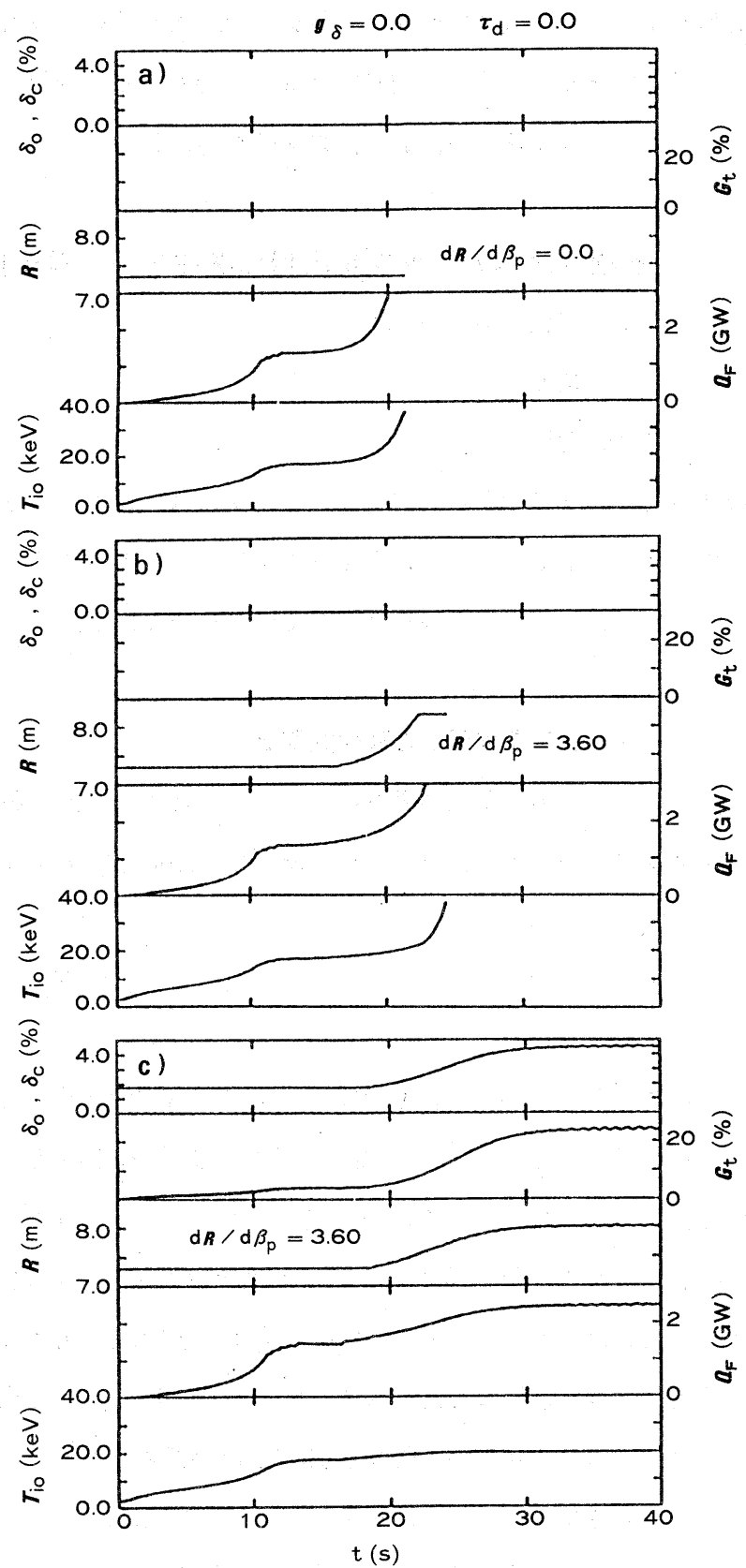

図 5.外部リップル $\delta_{c}$ を制御しない場合のプラ ズマ中心イオン温度 $T_{i 0}$, 核融合出力 $Q_{F}$, プラズマ主半径 $R, \quad \alpha$ 粒子リップル損失 $G_{\mathrm{t}}$, 及びトーラス外側端リップル $\delta 。$ の時 間変化. (a) プラズマ主半径の自由膨脹, $\alpha$ 粒子のリップル損失のいずれも考えない 場合，(b)，プラズマの主半径膨脹のみを 考えた場合 $\left(\mathrm{d} R / \mathrm{d} \beta_{\mathrm{p}}=3.6\right) ，(\mathrm{c})$ 両者を 考慮した場合. 


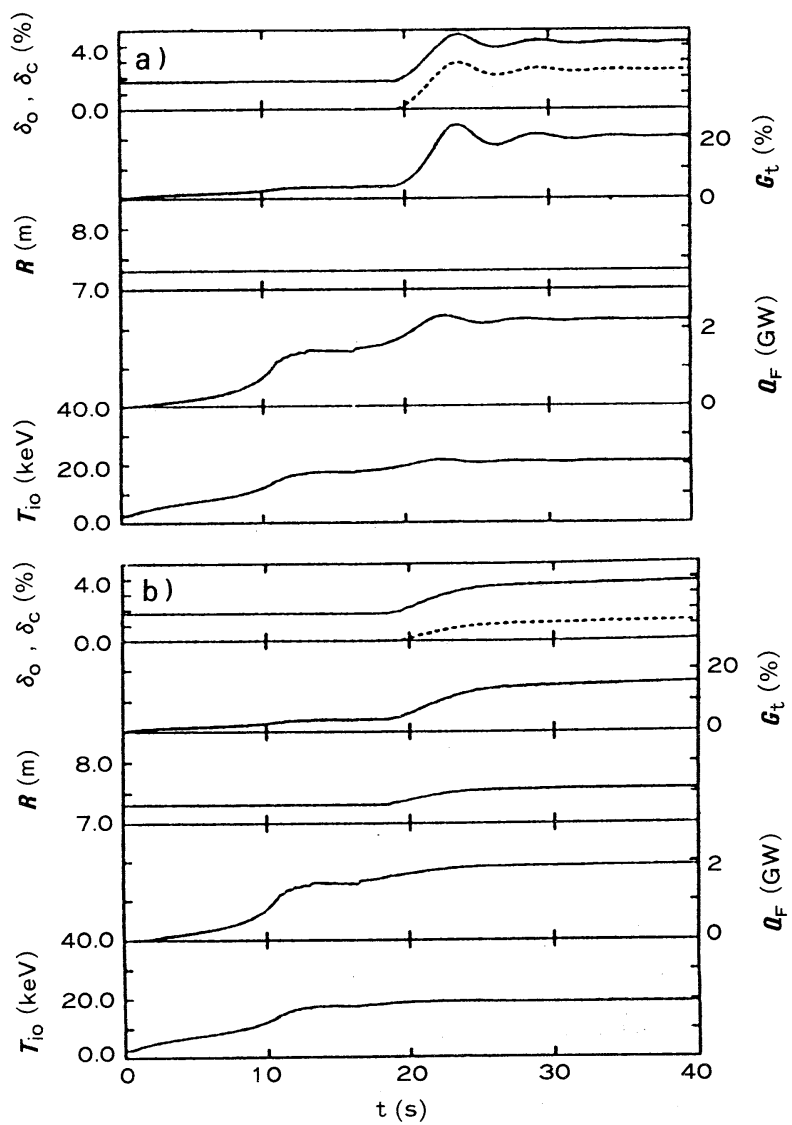

図 6. 外部リップル $\delta_{c}$ (点線) をフィードバッ ク出力 $Q_{\mathrm{F}}$, プラズマ半径 $R, \alpha$ 粒子リッ プル損失 $\mathrm{G}_{\mathrm{t}}$, 及びトーラス外側端リップル $\delta 。$ の時間変化. (a) プラズマ主半径の 自由膨脹を考えない場合. (b) プラズマ 主半径の自由膨脹を考えた場合.
值で燃焼制御が可能であることが示されてい る。

\section{3ー2) リップルを利用した燃料補給}

ITER など核融合炉における燃料補給法とし ては,これまで

(1)ガスパフ

(2)ペレット入射

が主として考えられて来た。しかし，ガスパフ は，トリチウムインベントリーの量が多くなる 問題があり，また，プラズマ周辺の中性粒子密 度を上げるため, バルクイオンの荷電交換損失 量が大きくなり，それによる真空容器第 1 壁上 のエロージョンの問題が指摘されている ${ }^{24)}$. 一方，(2)ペレット入射は，現在これまで数多く の核融合装置で採用され，プラズマ性能向上に その有効性が実証されてきたものの, 将来の核 融合炉への応用には

・電流駆動と同時使用できない。

・プラズマを一時的に冷却し，核融合出力 を変動させる。

など，依然多くの問題を含んでいる.

そこで，出来る限りプラズマ中心近く $(<0.5 a)$ への然料補給がプラズマを冷却することなく行える可能 性のある方法として, リップル捕捉粒子の $\nabla B$ ドリフト運動により，等価的に NBI のプラズマへの侵入樑

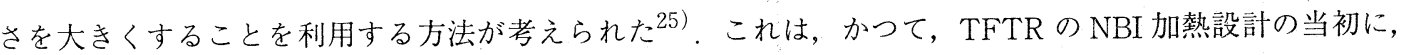

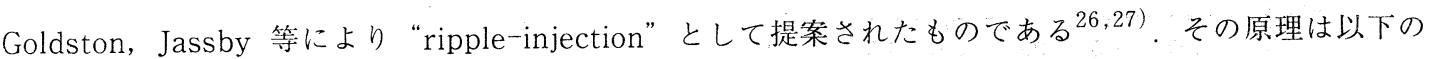
通りである。図 7 に示すように，水平面に対して上下非対称なリップルを外部のリップルコイルで作り出 し，ハッチングで示したリップルのウェルが形成される $\alpha *<1.0$ の領域にリップルの深い下側から垂直に

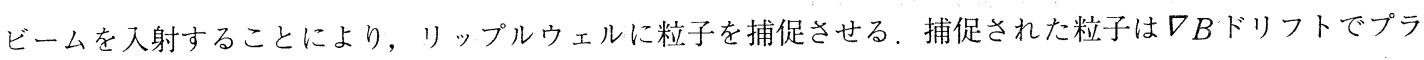
ズマの中心に向かって運動するが，中心に行くに従ってリップルウェルの深さは段々浅くなるため，あるい は，ドリフト運動の間にクーロン散乱を受け，リップルから離脱してバナナ粒子としてプラズマに閉じ込め られる。 


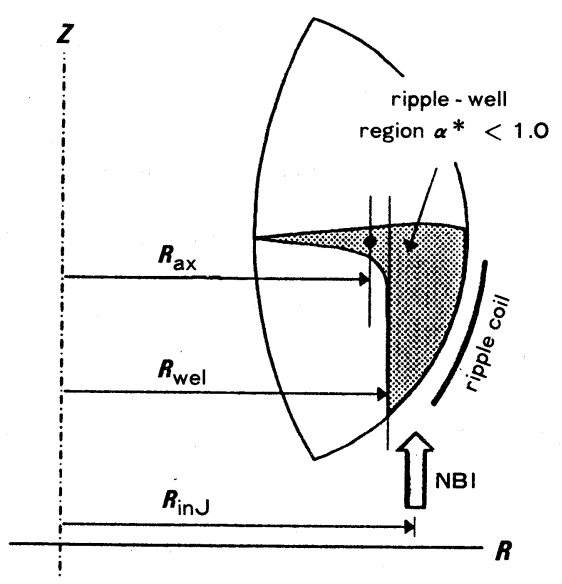

図 7.リップル燃料補給概念図

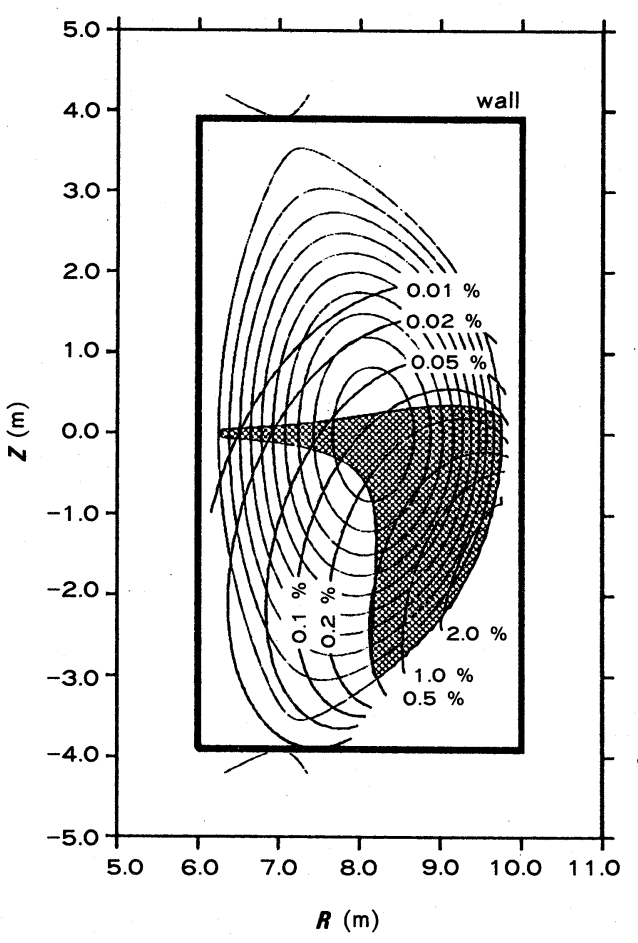

図 8.リップル燃料補給計算のためのリップ ル分布, MHD 平衡, 真空容器第 1 壁形 状
しかし，これらのバナナ粒子は，リップルの影 響でかなりの割合がプラズマから失われるのでは ないかと指摘され28). その後このアイデアは埋 れたままになっていた。一般に, “rippleinjection”をプラズマ加熱に応用する場合に比 べて燃料補給への応用は，ビームのエネルギー $E_{\mathrm{b}}$ を低く設定できる，このため，入射粒子の熱 化するまでの時間が短く，その間に発生する損 失も低くなることが期待される，そこで，この リップルを利用する燃料補給法（以下 ripple fueling, リップル燃料補給と称する) の検討が OFMC コードを用いて行われた，計算は，まず， 核融合出力 $3 \mathrm{GW}$ クラスの炬で，表 4 に示すパラ メー夕, 図 8 に示す MHD 平衡及び上下非対称 リップル分布について行われた。図 7 に示される ように，水平面下側で $\alpha^{*}<1.0$ の領域のトーラ ス内側端の主半径位置を $\mathrm{R}_{\mathrm{wel}}$, 垂直に入射する $\mathrm{NBI}$ の主半径位置を $R_{\mathrm{inj}}$ とする，図 9 に， $R_{\mathrm{wel}}$ $\sim 8.2 \mathrm{~m}, R_{\mathrm{ax}}=8.18 \mathrm{~m}$ の幾何形状の場合におい て, $150 \mathrm{keV}$ のトリチウムビームを $\mathrm{R}_{\mathrm{inj}}=8.5 \mathrm{~m}$, トロイダル角位相 $\phi_{0} / \phi_{\mathrm{N}}=0.4$ に入射した場合 の入射イオン分布のピィンチングの様子を示す. 図中の $\tau_{\mathrm{gd}}$ は

$$
\begin{gathered}
\tau_{\mathrm{gd}}=a / V_{\mathrm{gd}} \\
V_{\mathrm{gd}}: \nabla B \text { ドリフト速度 }
\end{gathered}
$$

で定義される $\nabla \mathrm{B}$ ドリフト時間である，時間 $t=$ 0.0は，いわゆる高速イオンの “birth profile” であるが,このようにトリチウムビームでは $150 \mathrm{keV}$ でも0.8 0.9a 程度までしか侵入できな い. 非円形効果で, 約 $1.4 \tau$ gd で分布のピーク点 
表 4 リップル燃料補給計算パラメータ

\begin{tabular}{|c|c|}
\hline mafor radius & $R_{\mathrm{t}}=8.0 \mathrm{~m}$ \\
\hline major radius of magnetic axis & $R_{\mathrm{ax}}=8.18 \mathrm{~m}$ \\
\hline minor radius & $a=1.75 \mathrm{~m}$ \\
\hline toroidal field & $B_{t}=11 \mathrm{~T}$ \\
\hline \multirow[t]{4}{*}{ plasma temperature } & $T_{\mathrm{e}}(\psi)=T_{\mathrm{e} 0}(1-\psi)$ \\
\hline & $T_{\mathrm{i}}(\psi)=T_{\mathrm{i} 0}(1-\psi)$ \\
\hline & $T_{\mathrm{D}}(\psi)=T_{\mathrm{T}}(\psi)=T_{\mathrm{i}}(\psi)$ \\
\hline & $T_{\mathrm{e} 0}=T_{\mathrm{i} 0}=25 \mathrm{keV}$ \\
\hline \multirow[t]{3}{*}{ plasma density } & $n_{\mathrm{e}}(\psi)=n_{\mathrm{e} 0}(1-\psi)^{0.5}$ \\
\hline & $n_{\mathrm{D}}(\psi)=n T(\psi)$ \\
\hline & $n_{\mathrm{e} 0}=2 \times 1020 \mathrm{~m}^{-3}$ \\
\hline \multirow[t]{2}{*}{ plasma current } & $l p=15 \mathrm{MA}$ \\
\hline & $j(\psi)=j_{0}(1-\psi)^{0.5}$ \\
\hline ellipticity & $k=2.0$ \\
\hline triangularity & $\Delta=0.4$ \\
\hline effective $Z$ & $z_{\text {eff }}=1.5$ (uniform) \\
\hline charge number of impurity & $z_{i m p}=8.0$ (oxygen) \\
\hline number of ripple coils & $N=12$ \\
\hline
\end{tabular}

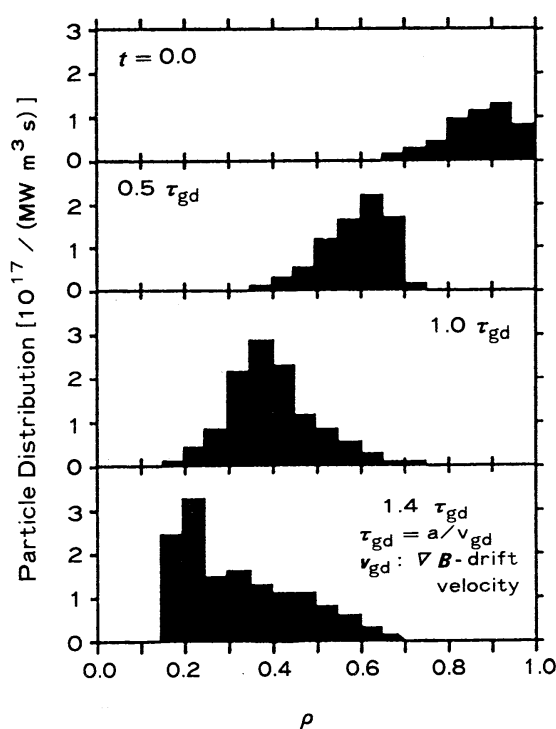

図 9.入射粒子の $\nabla B$ ドリフトによる ピィンチング過程.入射イオンは

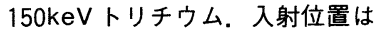
$R_{\mathrm{inj}}=8.5 \mathrm{~m}$, トロイダル角位相 $\phi_{0} / \phi_{\mathrm{N}}=0.4 . R_{\mathrm{wel}} \sim 8.2, R_{\mathrm{ax}}$ $=8.18 \mathrm{~m}$.

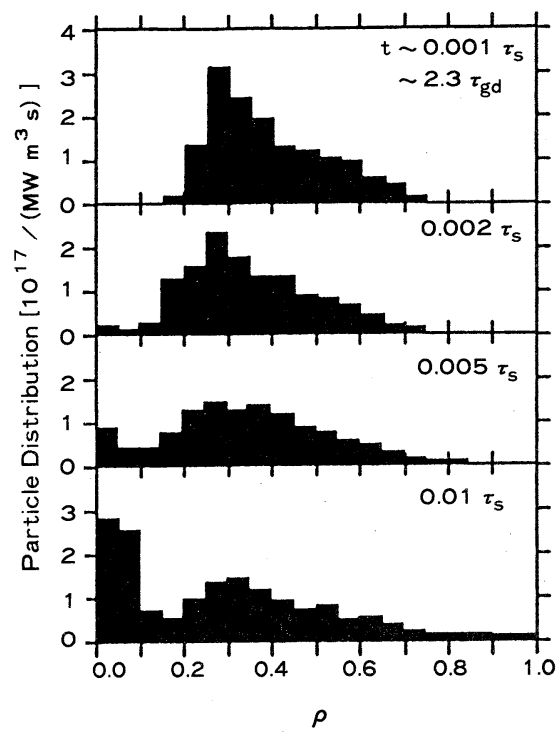

図10.リップル離脱バナナ粒子の拡散 過程. 入射イオンは $150 \mathrm{keV} ト$ リチウム. 入射位置は $R_{\mathrm{inj}}=$ $8.5 \mathrm{~m}$ ，トロイダル角位相 $\phi_{0}$ / $\phi_{\mathrm{N}}=0.4$. $R_{\mathrm{wel}} \sim 8.2, R_{\mathrm{ax}}=$ $8.18 \mathrm{~m}$.
は最もプラズマ中心に近づく． $R_{\mathrm{inj}}=8.5 \mathrm{~m}$ であるので 規格化半径 $\rho$ では $\left(R_{\mathrm{inj}}-R_{\mathrm{ax}}\right) / a \sim 0.17$ 以内には高速 イオンは原理的に侵入できない. $t=1.4 \tau_{\mathrm{gd}}$ での分布 の拡がりは,ピィンチングの途中でクーロン衝突により リップルから離脱したバナナ粒子によるものである。さ らに時間を長く観測した場合，図10に示すようにリッ プル励起バナナドリフトでプラズマ中心, 周辺の両方向 に拡がり， $\rho<0.17$ の心部にも一部の粒子が供給され る。さらに，詳細な解析により，ビームエネルギーのプ ラズマ電子温度に対する比 $E_{\mathrm{b}} / \tau_{\mathrm{eo}}$ を 4 以下に設定す れば，燃料補給率としては $80 \%$ 以上が期待でき，リップ ル燃料補給の有効性が示された。

しかし前述のようにリップル燃料補給の有効性は, 用いるリップルによる $\alpha$ 粒子の損失により決定される. 


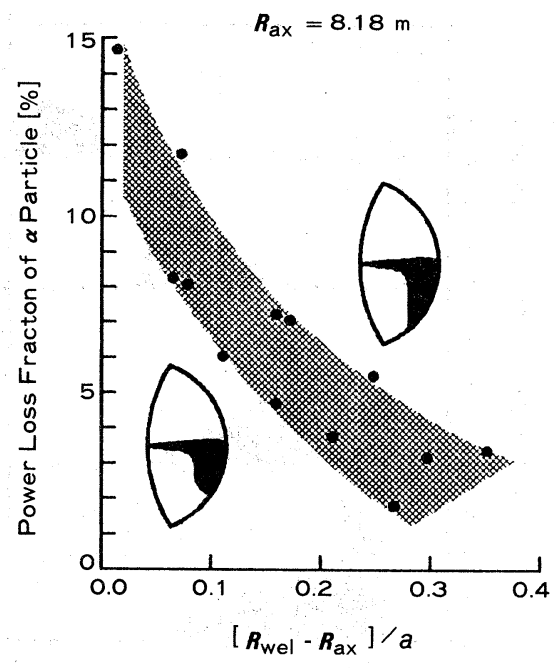

図11.リップル燃料補給における $\alpha$ 粒子 パワー損失のリップル分布 $\left(R_{\text {wel }}\right)$ 依存性。

そこで， $R_{\mathrm{wel}}$ の位置を変えた種々のリップル分布にお ける $\alpha$ 粒子のパワー損失比が OFMC を用いて求められ た。結果を困11に示す。困中○は，計算点を示す。八ッ チング領域の上限は, 図にも示すように水平面下側で $\alpha^{*}<1.00$ 領域のトーラス内側端が水平面に対して垂 直となるようにリップル分布を設定した場合のものであ る。リップル燃料補給を実際に核融合炉に応用するとな ると, NBI の入射角としては, 磁力線に垂直であっても 水平面に対して多少斜めに設定する方が，入射ポートの 十分な断面積を確保することからも有利と思われる。こ の場合， $\alpha^{*}<1.0$ の領域の下端一部は不要となる. 図11のハッチング領域の下端近くは，図中に示すよう な, $\alpha^{*}<1.0$ の下端の一部を切り久くリップル分布に おける $\alpha$ 粒子損失を示す。このように， $\alpha$ 粒子のリップ

ル損失は，リップル分布を調整することにより，5\%以下の低い值に抑えることが可能であることが示され ている。 また,このときの損失粒子による真空容器第 1 壁上の熱負荷も，強制冷却を想定した水平面上トー ラス外側のリミッタ上で〜 $2 \mathrm{MW} / \mathrm{m}^{2}$ と許容範囲内であることも示された。

\section{4. おわりに}

以上，ITERにおいて最近行われたベンチマークテスト結果を中心に現在各国で行われている， $\alpha$ 粒子の 減速過程におけるリップル損失の検討状況を紹介した。また，核融合におけるリップル応用に関連する $\alpha$ 粒 子のリップル損失に関する最近の検討結果をまとめた.

核融合炉における $\alpha$ 粒子の閉じ込め，特にリップル損失は，トロイダル磁場コイル設計，真空容器第 1 壁

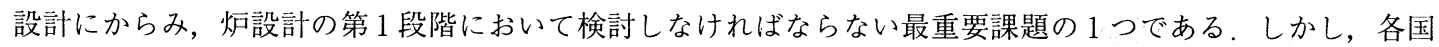
で払われている努力は, 問題の重要性の割には少ないように見える，その最大の原因は，主たる解析手段で ある OFMC コードの計算に要する CPU 時間があまりに長く，検討そのものが非常に高価であることにあ る.

今後，高並列計算機の導入，あるいは新しい解析手法の確率が待たれる。筆者の経験からすれば，後者の 開発も OFMC コードの結果とのクロスチェックが不可欠であり，やはり OFMC コードの高速化が今後とも重 要であることには変わりはないものと考えられる.

$\alpha$ 粒子のリップル損失に関してもう 1 つ重要な点は，検討が依然として OFMC コードを中心とする数值解 析が中心であり，実験的検討がまだほとんどなされていないことである， $\alpha$ 粒子については，TFTRの実験 
が大いに期待されるところであるが，測定が非常に困難であるため，定量的評価がどの程度可能であるかに ついては疑問とされている。当面は，JT-60Uなどにおける NBI加熱のリップル損失実験等で，実験と数値 解析のクロスチェックを積み重ねていく必要があろう.

リップル核融合炉への応用の検討も着実に進められている。しかし，まだ数值解析を用いてそれ等の可能 性が示された段階である，今後，核燃焼抑制については，現在想定される種々のエネルギー閉じ达め則にお ける抑制特性, 必要な外部リップルコイルとその電源容量など，核融合炉への応用の具体的検討が必要とな ろう。また，燃料補給についても，アルファ粒子損失をより少なくする工夫，あるいは，その核燃焼抑制へ の応用の可能性の検討などが今後の課題となろう.

\section{謝辞}

本稿をまとめるにあたり有益な議論をいただきました, 京都大学へリオトロン核融合研究センターの若谷 誠宏教授をはじめとする「高速イオン及びアルファ粒子の物理研究」調査作業委員メンバーの皆様及び常松 俊秀主任研究員に感謝いたします。終始，御指導をいただきました吉川允二理事，飯島勉所長，田村早苗部 長, 島本進部長, 竹田室長の皆様に深く感謝いたします。

\section{参考文献}

1) M. Ohnishi, N Ao and J. Wakabayashi : Nucl. Fusion 18 (1978) 859.

2) K. Tani, M. Azumi, H. Kishimoto and S. Tamura: J. Phys. Soc. Jpn. 50 (1981) 1726.

3) K. Hanatani, M. Wakatani and K. Vo : Nucl. Fusion 21 (1981) 1067.

4) R. J. Goldston and H. H. Towner : J. Plasma Physics 26 (1981) 283.

5) S. Putvinskij et al. : "Alpha Particle Ripple Loss Meeting Summary Report," ITER-IL-PH-1-9-1.

6) K. Tani et al. : Nucl. Fusion 23 (1983) 657.

7) L.M. Hively : Nucl. Fusion 24 (1984) 779.

8) R.J. Goldston, R. B. White and A.H. Boozer : Phys. Rev. Lett. 47 (1981) 647.

9) V. Ya. Goloborod'ko et al. : Physica Scripta T16 (1987) 46.

10) R. B. White et al. : Plasma Phys. and Controll. Nucl. Fusion Research 1988 (Proc. 12th Int. Conf., Nice) IAEA, Vienna (1989) Vol. 2. 111.

11) V. Ya. Goloborod'ko et al. : Fusion Technology 18 (1990) 429.

12) K. Tani et al. : Plasma Phys, and Controll. Nucl. Fusion Research 1988 (Proc.12th Int. Conf., Nice) IAEA, Vienna (1989) Vol. 2. 121.

13) S.V. Konovalov et al. : “Alpha Portide Ripple Losses in ITER" , presented at the IAEA TCM on "Alpha Particles in Fusion Research" . Kiev USSR (1989).

14) E. Bittoni and M. Haegi : Fusion Technology 18 (1990) 373.

15) K. Tani and H. Kishimoto : Nucl. Fusion 22 (1982) 1108.

16) “ITER Conceptual Design Report” , ITER Documentation Series, No. 18, IAEA (1991).

17) T.E. Stringer : Nucl. Fusion 12 (1972) 289.

18) T.W. Petrie and J.M. Rawls : Nucl. Fusion 20 (1980) 419.

19) T.W. Petrie and J.M. Rawls : Nucl. Fusion 20 (1980) 1461.

20) M. Sugihara et al. : J. Nucl. Sci. Technol., 17 [10] (1980) 729.

21) K. Tani, H. Kishimoto and S. Tamura : Plasma Phys. and Controll. Nucl. Fusion Research 1980 (Proc. 8th Int Conf., Brusseles) IAEA, Vienna (1981) Vol.1 631. 


\section{核融合研究 第66巻第 1 号 1991 年 7 月}

22) R.E. Potok, P. A. Politzer and L. M. Lidsky : Phy. Rev. Lett. 20 (1980) 1328.

23) K. Tani et al. : Fusion Technology 18 (1990) 625.

24）上田憲昭 : 私信 (1990).

25) K. Tani et al. : to be submitted to Fusion Technology.

26) D. L. Jassby and R. J. Goldston : Nucl. Fusion 16 (1976)613.

27) D.L. Jassby : PPPL-1280.

28) R. J. Goldston and D.L. Jassby : Princeton Plasma Physics Lab. Rep. MATT-1244 (1976). 